\title{
FACTORS THAT INFLUENCE SURGICAL MARGIN STATE IN PATIENTS UNDERGOING COLD KNIFE CONIZATION - A SINGLE CENTER EXPERIENCE
}

\author{
Igor Aluloski ${ }^{1}$, Mile Tanturovski ${ }^{1}$, Gordana Petrusevska ${ }^{2}$, \\ Rubens Jovanovic ${ }^{2}$, Slavica Kostadinova-Kunovska ${ }^{2}$
${ }^{1}$ Department of Gynecologic Oncology, University Clinic of gynecology and obstetrics, University "Ss. Cyril and Methodius”, Skopje, Republic of Macedonia
${ }^{2}$ Institute for Pathology, Medical Faculty Skopje, University "Ss. Cyril and Methodius", Skopje, Republic of Macedoniats

Corresponding author: Igor Aluloski - Department for Gynecological Oncology, University Clinic for Obstetrics and Gynecology-Skopje, e-mail: i_aluloski@hotmail.com, adress: ul. Anastas Mitrev 29/10, Skopje

\section{ABSTRACT}

\begin{abstract}
Aim: To evaluate the factors that influence the surgical margin state in patients undergoing cold knife conization at the University Clinic of Gynecology and Obstetrics in Skopje, Republic of Macedonia

Materials and methods: We have retrospectively analyzed the medical records of all patients that underwent a cold knife conization at our Clinic in 2015. We cross-referenced the surgical margin state with the histopathological diagnosis (LSIL, HSIL or micro-invasive/invasive cancer), menopausal status of the patients, number of pregnancies, surgeon experience, operating time and cone depth. The data was analyzed with the Chi square test, Fisher's exact test for categorical data and Student's T test for continuous data and univariate and multivariate logistical regressions were performed.
\end{abstract}

Results: A total of 246 medical records have neen analyzed, out of which 29 (11.79\%) patients had LSIL, $194(78.86 \%)$ had HSIL and $23(9.34 \%)$ patients suffered micro-invasive/invasive cervical cancer. The surgical margins were positive in $78(31.7 \%)$ of the patients. The average age of the patients was 41.13 and $35(14.23 \%)$ of the patients were menopausal. The multivariate logistic regression identified preoperative forceps biopsy of micro-invasive SCC, HSIL or higher cone specimen histology and shorter cone depth as independent predictors of surgical margin involvement in patients undergoing cold knife conization.

Conclusion: In the current study, we have found no association between the inherent characteristics of the patient and the surgeon and the surgical margin state after a CKC. The most important predictors for positive margins were the severity of the lesion and the cone depth.

Keywords: Cold knife conization, residual disease, surgical margin

\section{INTRODUCTION}

Since the wide implementation of cervical cancer screening programs that utilize cervical cytological smears, the rates of cervical cancer in the developed western countries have dropped substantialy [1]. The effect of these early detection programs depends not only on the sensitivity of the cytological smears, but also on the ability to successfully treat the precancerous lesions identified by the screening tests. At the same time, this improvement led to rising incidence rates of pre- cancerous lesions of the uterine cervix, especially among women of reproductive age $[2,3]$. Ting et al. has systematically reviewed 103 studies with data from more than 12 million patients [4]. The authors have found that the incidence of high-grade squamous intraepithelial lesions (HSIL) in European women peaks in women between the age of 30 and 40. The peak age of incidence of low-grade lesions (LSIL) is much lower than HSIL. 
Because of the $5-12 \%$ chance of progression to squamous cell cancer, management guidelines recommend treatment for women with moderate-to-severe dysplasia [5]. Surgical treatment irrespective of the type, be it LEEP/LLEETZ, laser or cold knife cone biopsy, reduces the volume of cervical tissue and the length of the cervical canal, leading to specific local immunologic and fibrotic tissue reactions, cervical stenosis, preterm delivery and infertility [6]. In young women desiring future pregnancies, excisional procedures are balanced between complete excision of the lesion and minimal cervical damage in an attempt to reduce the risk of unfavorable obstetric outcomes. Bearing in mind that most women in this age group have not completed their reproduction at the time of diagnosis, one could certainly see the challenge this imposes on the surgeons. Surgical margin involvement is associated with an increased risk of residual/recurrent disease. A comprehensive meta-analysis [7] included data from 35109 patients, 8091 of which $(23.04 \%)$ had at least one disease-involved excisional margin. The authors calculated that, following incomplete excision, the relative risk (RR) of post treatment disease of any grade was $5.47(95 \%$ CI 4.37-6.83) and RR of high-grade disease (HSIL) was 6.09 (3.87-9.60) compared with the reference group who had a complete excision [7]. Oliveira et al. in their meta-analysis found the relative risk of persistent/recurrent HSIL one year after treatment to be 11.36 in patients with positive margins, compared to patients with negative margins [8]. Older patients [9], patients with higher parity [10], higher CIN grade [11] and/or smaller cone depth [12] have been reported to be at an increased risk of having positive surgical margins.

\section{AIM}

The aim of the study is to evaluate the factors that influence the surgical margin state in patients undergoing cold knife conization at the University Clinic of Gynecology and Obstetrics in Skopje, Republic of Macedonia.

\section{MATERIAL AND METHODS}

We conducted a retrospective cross-sectional study on the data form the registers of University Clinic for gynecology and obstetrics, University "Ss. Cyril and Methodius", Skopje, Republic of
Macedonia in the timeframe January - December 2015. We only included patients that underwent cold knife conization that had pathohistological reports that clearly defined cone margin state. We identified a total of 253 patient records; where 246 patients $(97.23 \%)$ met the inclusion criteria, while 7 patients were excluded due to inadequate pathohistology reports (fragmented cone samples and/or inability to evaluate cone margin state). The following variables were recorded from the medical charts for each patient: age, parity, menopausal status, pre-treatment biopsy results, surgeon experience (defined as experienced if he/she had performed at least 200 cold knife conizations, otherwise inexperienced) and operating time. All specimens were analyzed at the Institute of $\mathrm{Pa}$ thology, University "Ss. Cyril and Methodius", Skopje, Republic of Macedonia. The extent of the lesion, cone base length and width, cone depth (height) and margin status were recorded from the final pathology report for each patient. The volume of each specimen was approximated using the elliptic cone volume formula (using the cone base length and width and the cone depth from the pathology report).

We formulated the following hypotheses:

Hypothesis 1: the severity of the disease in the preoperative forceps biopsy and the cervical conization specimen increases, so does the percentage of patients who have positive surgical margins.

Hypothesis 2: advanced patient age and/or menopause increases the risk of disease-involved margins in the cone sample.

Hypothesis 3: Precancerous lesions of the uterine cervix tend to recur even after complete resection of the initial lesion (i.e. the surgeon has achieved clear margins) because of the viral etiology of the lesion. The persistence of viral infection after the surgery increases the risk of recurrent disease and/or de novo lesion formation.

All statistical calculations were done using IBM SPSS Statistics software package, version 20.0. A probability value of $p \leq 0.05$ was considered significant. The differences between discrete variables were tested using Chi-square test and Fisher's exact test (where appropriate). Student's $t$ test was used to test the statistical significance of the differences between the continuous variables. A multivariate logistic regression was carried out to identify the independent risk factors and odds ratios (ORs) with 95\% confidence intervals were calculated for each outcome. 


\section{RESULTS}

We identified a total of 246 patient records that met the inclusion criteria. The average age of the patients was 41.13 years ( \pm 10.76 years) with a range from 21 to 78 years. The patients had 2.31 pregnancies $( \pm 1.72$, range $0-10)$ and 1.66 deliveries $( \pm 1.19$, range $0-8)$ on average. Thirty-five $(14.2 \%)$ of the patients were menopausal, while the rest of the patients were premenopausal. The preoperative colposcopy-guided forceps biopsy revealed HSIL lesions in $238(96.75 \%)$ of the patients, while $8(3.25 \%)$ patients had micro-invasive squamous cell carcinoma. 51 (21.43\%) of the patients with HSIL lesions, had moderate cervical dysplasia, $110(46.22 \%)$ had severe cervical dysplasia and 77 (32.35\%) had in situ squamous cervical carcinoma. 168 patients $(68.3 \%)$ had negative cone margins, while $78(31.7 \%)$ had at least one disease-involved margin (endocervical or exocervical). The postoperative histology verified LSIL lesions in $29(11.79 \%)$ of the patients, HSIL lesions in $194(78.86 \%)$ of the patients [of which $49(25.26 \%)$ patients had moderate cervical dysplasia, 76 (39.18\%) had severe cervical dysplasia and 69 (35.56\%) had in situ squamous cervical carcinoma], while $23(9.34 \%)$ patients had invasive squamous cell carcinoma. The average cone depth was $15.28 \mathrm{~mm}$ (range $4-30 \mathrm{~mm}$ ) with a standard deviation of $5.8 \mathrm{~mm}$, while the average cone volume was $3.51 \mathrm{~cm} 3 \pm 2.9 \mathrm{~cm} 3$ (range 0.19 $13.67 \mathrm{~cm} 3)$. One hundred and fifty-five $(63.01 \%)$ conizations were performed by experienced surgeons, $91(36.99 \%)$ were performed by inexperienced surgeons with an average operating time of $35.33 \pm 10.43$ minutes for all surgeons. Table 1 summarizes the patient characteristics, while table 2 presents the histopathologic results from the conizations.

Table 3 outlines the differences between the patients with negative cone margins and the patients with disease-involved surgical margins.

In our series, patients were more likely to have disease involved margins if they were older $(p<0.001)$, menopausal $(p=0.001)$, had more pregnancies $(p=0.03)$, had a lesion of higher grade both on the preoperative biopsy and in the cone specimen ( $\mathrm{p}=0.001$ and $<0.001$, respectively) and if they had shallower and smaller blocks of tissue excised ( $p<0.001$ and 0.04 , respectively). The differences in parity, surgeon experience and operating time between the groups were not statistically significant.

Next, we included the identified potential risk factors (age, number of pregnancies, menopausal status, preoperative biopsy, cone histology, cone depth and cone volume) in a multivariate logistic regression analysis. The following independent risk factors for disease-involved surgical margins were identified: preoperative forceps biopsy of micro-invasive SCC (OR=17.97; 95\%CI

Table 1. Summary of patient characteristics

\begin{tabular}{lr}
\hline Characteristic & \\
\hline Age $($ mean $\pm S D)$ & $41.13 \pm 10.76$ years \\
No. of pregnancies (mean $\pm S D)$ & $2.31 \pm 1.72$ pregnancies \\
Parity (mean $\pm S D)$ & $1.66 \pm 1.19$ deliveries \\
Menopausal status & $211(85.77 \%)$ \\
Premenopausal $(n, \%)$ & $35(14.23 \%)$ \\
Postmenopausal $(n, \%)$ & $238(96.75 \%)$ \\
Preoperative forceps biopsy histology & $8(3.25 \%)$ \\
HSIL ( $n$, \%) & \\
Squamous cell carcinoma $(n, \%)$ & 91 (36.99\%) \\
Surgeon experience & 155 (63.01\%) \\
Inexperienced $(n, \%)$ & $35.33 \pm 10.43$ minutes \\
Experienced $(n, \%)$ &
\end{tabular}


Table 2. Pathological features of the specimens

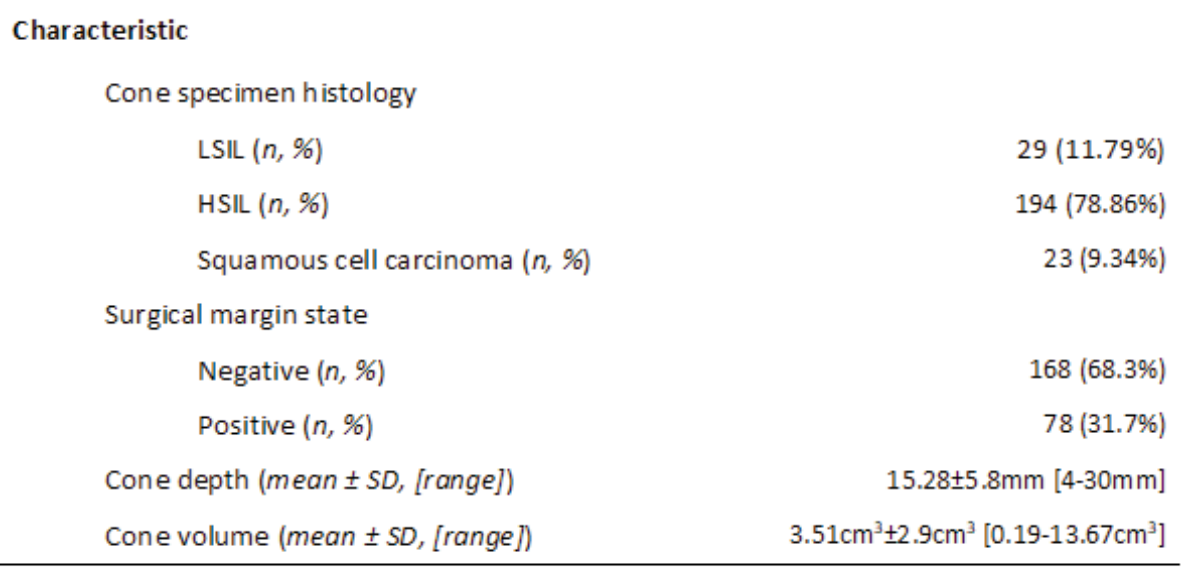

Table 3. Distribution of the analyzed variables with regard to surgical margin state

\begin{tabular}{|c|c|c|c|}
\hline \multirow{2}{*}{ Variable } & \multicolumn{2}{|c|}{ Margin state } & \multirow[b]{2}{*}{$\mathrm{p}$} \\
\hline & Negative $(n=168)$ & Positive $(n=78)$ & \\
\hline Age (mean) & 39.47 years & 44.72 years & $<0.001^{\ddagger}$ \\
\hline No. of pregnancies (mean) & 2.13 & 2.69 & $0.027^{\ddagger}$ \\
\hline Parity (mean) & 1.56 & 1.87 & $0.084^{*}$ \\
\hline Menopausal status & & & $0.001^{+}$ \\
\hline Premenopausal & $153(72.5 \%)$ & $58(27.5 \%)$ & \\
\hline Postmenopausal & $15(42.9 \%)$ & $20(57.1 \%)$ & \\
\hline $\begin{array}{l}\text { Preoperative forceps biopsy } \\
\text { histology }\end{array}$ & & & $0.001^{+}$ \\
\hline $\operatorname{HSIL}^{*}(n, \%)$ & $167(70.5 \%)$ & $70(29.5 \%)$ & \\
\hline $\operatorname{scc}^{*}(n, \%)$ & $1(11.1 \%)$ & $8(88.9 \%)$ & \\
\hline Surgeon experience & & & $0.671^{+}$ \\
\hline Inexperienced $(n, \%)$ & $64(70.3 \%)$ & $27(29.7 \%)$ & \\
\hline Experienced $(n, \%)$ & $104(67.1 \%)$ & $51(32.9 \%)$ & \\
\hline Operating time (mean) & $35.12 \mathrm{~min}$ & $35.77 \mathrm{~min}$ & $0.65^{\ddagger}$ \\
\hline Cone specimen histology & & & $<0.001^{+}$ \\
\hline $\operatorname{LSIL}^{*}(n, \%)$ & $25(86.2 \%)$ & $4(13.8 \%)$ & \\
\hline $\operatorname{HSIL}^{*}(n, \%)$ & $137(70.6 \%)$ & $57(29.4 \%)$ & \\
\hline $\operatorname{SCC}^{*}(n, \%)$ & $6(26.1 \%)$ & $17(73.9 \%)$ & \\
\hline Cone depth (mean) & $16.34 \mathrm{~mm}$ & $13 \mathrm{~mm}$ & $<0.001^{\ddagger}$ \\
\hline Cone volume (mean) & $3.79 \mathrm{~cm}^{3}$ & $2.91 \mathrm{~cm}^{3}$ & $0.04^{\ddagger}$ \\
\hline
\end{tabular}

"LSIL - low-grade squamous intraepithelial lesions; HSIL - high-grade squamous intraepithelial lesions; SCC- microinvasive/invasive squamous cell carcinoma. 'Chisquare test; 'Student's t-test. 
1.6-20.17; $\mathrm{p}=0.019)$, HSIL or higher cone specimen histology $(\mathrm{OR}=3.76$; 95\% CI 1.58-8.92; $\mathrm{p}=0.003)$ and cone depth $(\mathrm{OR}=0.87$ for every $\mathrm{mm}$ of cone depth; $95 \%$ CI $0.8-0.95 ; \mathrm{p}=0.002)$. Since cone depth was a continuous variable in the logistic regression, we used the regression analysis to extrapolate the optimal cone depth from the logit function. The minimal cone depth that achieves a negative margin rate of $90 \%$ in the analyzed series was $21.56 \mathrm{~mm}$.

\section{DISCUSSION}

Cervical cancer is the second most common malignancy affecting women in the Republic of Macedonia, but the mortality rate has declined with the organized efforts to detect precancerous lesions earlier via cytological smears [13]. This, in turn increased the need for more conservative treatment, as most of these precursor lesions are identified in women in their twenties [14], which means the treatment choice will impact the future reproductive health of the patients.

The aim of our study was to assess the factors that influence the surgical margin state in patients undergoing cold knife conization at our center.

In the analyzed series, $31.7 \%$ of the patients had positive surgical margins. The rate of margin involvement varies greatly in the published studies: $7.2-42.5 \%$ [15-17], and is mostly dependent on the margin type. Authors that consider endocervical margins regardless of the ectocervical margin involvement, approximate the margin involvement rate at $10 \%[15,16,18]$. Studies that analyzed hysterectomy specimens have estimated the rates of disease recurrence and residual disease at $5-10 \%$ and $20-35 \%$, respectively. It is more than clear from the published data that patients with incomplete excision of intraepithelial cervical lesions must be treated and that these lesions recur even after a complete resection of the initial lesion (i.e. the surgeon has achieved clear margins). This is due to the viral etiology of the lesion; even though the surgery is sufficient to treat the lesion itself, it does nothing for the treatment of the pathogen. The persistence of the viral infection, increases the risk of recurrence and/or de novo lesion formation. Furthermore, the authors have shown that the follow-up of patients after an excisional procedure is paramount for the early detection of residual and/or recurrent disease $[15,18,19]$. Still, recurrence and/or persistence of CIN is more frequent in patients with positive surgical margins after an excisional procedure (conization, LEEP/LEETZ...) [19]. However, one should always bear in mind that the majority of patients with positive margins remain disease-free throughout the entire follow-up period [15]. Therefore, most published studies recommend that the managed of patients with margin involvement be tailored to the patient's individual needs, taking into consideration the age, patient preference, reproductive plans, risk of potential complications from further treatment and the desire to eradicate the potential residual lesion.

In the current series, the descriptive statistics found significant differences between patients with positive and negative surgical margins on the basis of age, parity and menopausal status. This is probably due to the fact that the squamocolumnar junction of the cervix tends to be retracted within the cervical canal in postmenopausal women, which increases the risk of positive stromal margins. However, the subsequent logistic regression failed to identify these factors as independent risk factors for positive cone margins, which is in concordance with literature data [20].

We found that as the severity of the disease in the preoperative forceps biopsy and the cervical conization specimen increases so does the percentage of patients who have positive surgical margins. Patients with micro-invasive SCC on the preoperative forceps biopsy had an OR of 17.97 (95\%CI 1.6-20.17; $\mathrm{p}=0.019)$, positive surgical margins, while patients with HSIL or higher on the cone specimen had an OR of $3.76(95 \% \mathrm{CI}$ $1.58-8.92 ; \mathrm{p}=0.003)$, margin involvement.

Chang et al.21 also published similar results. In their study, patients with HSIL, micro-invasive SCC and invasive SCC identified in the conization specimen had positive surgical margins in $23 \%$, $23.8 \%$, and $43.8 \%$ of the cases, respectively.

Our data showed that the average cone depth was significantly different between patients with negative and positive margins $(16.34 \mathrm{~mm}$ vs. $13 \mathrm{~mm}$ ) and the subsequent logistic regression analysis identified this parameter as an independent risk factor for margin involvement. We found that the minimal cone depth that achieves a negative margin rate of $90 \%$ in the analyzed series was $21.56 \mathrm{~mm}$.

Klieamnn and colleagues found that the mean depth of the cone specimens were $17.1 \mathrm{~mm}$ 
and $22.4 \mathrm{~mm}$ in patients with positive and negative surgical margins [22]. On the other hand, Papoutsis et al. [23] calculated that the optimal cone depth to achieve clear surgical margins was $10 \mathrm{~mm}$, while Milinovic and colleagues [24] found that cone depth of $15 \mathrm{~mm}$ for nulliparous and $18 \mathrm{~mm}$ for multiparous women were sufficient to achieve a negative endocervical margin. It is important to note, however, that the last two cited studies analyzed data from younger patients and did not include patients with carcinoma in situ, micro-invasive SCC or SCC lesions on the conization specimen histology. It should be noted, however, that deeper cone specimens are associated with a greater risk of cervical canal stenosis [25], intraoperative bleeding [26] and subsequent obstetric complications (cervical incompetence) [27]. Therefore, one should always weigh the potential of positive surgical margins and/or residual disease against the potential risk of complications and the reproductive plans of the patient.

In conclusion, we found that preoperative forceps biopsy of micro-invasive SCC, HSIL or higher cone specimen histology and shorter cone depth were independent predictors of surgical margin involvement after a cold knife conization. The optimal cone length to achieve a negative surgical margin in $90 \%$ of the cases was $21.56 \mathrm{~mm}$. The inherent characteristics of the patient (age, parity, menopausal status) and surgeon experience did not influence the surgical margin state after a cold knife conization.

Ethics Committee Approval: the study has received approval from the ethics committee of the Medical faculty, University "Ss. Cyril and Methodius", Skopje, Republic of Macedonia.

Conflict of Interest: No conflict of interest was declared by the authors.

Financial Disclosure: The authors declared that this study has received no financial support.

Authors' contributions

AI designed the study, collected the data, reviewed the data and wrote the manuscript, MT collected the data, did the data analysis and wrote the manuscript. PG reviewed the data, JR reviewed the data, KKS collected the data. All authors have read and approved the final manuscript.

\section{REFERENCES}

1. Horner MJ, Ries LA, Krapcho M, et al. SEER cancer statistics review, 1975-2006. Available at: $\mathrm{http} / / /$ seer.cancer.gov/csp/1975_2006.

2. Crane JM. Pregnancy outcome after loop electrosurgical excision procedure: a systematic review. Obstet Gynecol 2003;102:1058-62.

3. Kainz C, Gitsch G, Heinzl Hm Breitenecker G. Incidence of cervical smears indicating dysplasia among Austrian women durign the 1980s. Br. J Obstet Gynaecol 1995;102:541-4.

4. Ting J, Kruzikas DT, Smith JS. A global review of age-specific and overall prevalence of cervical lesions. International Journal of Gynecological Cancer 2010;20:1244-9.

5. Massad LS, Einstein MH, Huh WK et al. 2012 updated consensus guidelines for the management of abnormal cervical cancer screening tests and cancer precursors. Obstet Gynecol. 2013 Apr;121(4):829-46.

6. Kyrgiou M, Kaliopoulos G, Martin - Hirsch P. Obstetric outcomes after conservative treatment for intraepithelial or early invasive cervical lesions: systematic review and meta-analysis. Lancet 2006;367:489-98.

7. Ghaem-Maghami S, Sagi S, Majeed G, Soutter WP. Incomplete excision of cervical intraepithelial neoplasia and risk of treatment failure: a meta-analysis. Lancet Oncol. 2007;8(11):985-93.

8. Oliveira CA, Russomano FB, Gomes Júnior SC, Corrêa FM. Risk of persistent high-grade squamous intraepithelial lesion after electrosurgical excisional treatment with positive margins: a meta-analysis. Sao Paulo Med J 2012;130:119-25.

9. Lu CH, Liu FS, Kuo CJ, Chang CC, Ho ES. Prediction of persistence or recurrence after conization forcervical intraepithelial neoplasia III. Obstet Gynecol 2006;107:830-5.

10. Tillmanns TD, Falkner CA, Engle DB, Wan JY, Mannel RS, Walker JL, et al. Preoperative predictors of positive margins after loop electrosurgical excisional procedure-Cone. Gynecol Oncol 2006;100:379-84.

11. Paraskevaidis E, Lolis ED, Koliopoulos G, Alamanos Y, Fotiou S, Kitchener HC. Cervical intraepithelial neoplasia outcomes after large loop excision with clear margins. Obstet Gynecol 2000;95:828-31. 
12. Kietpeerakool C, Khunamornpong S, Srisomboon J, Siriaunkgul S, Suprasert P. Cervical intraepithelial neoplasia II-III with endocervical cone margin involvement after cervical loop conization: is there any predictor for residual disease? J Obstet Gynaecol Res 2007;33:660-4.

13. Ferlay J, Shin HR, Bray F, Forman D, Mathers C, Parkin DM. Estimates of worldwide burden of cancer in 2008: GLOBOCAN 2008. Int J Cancer. 2010;127(12):2893-917.

14. Herbert A, Smith JA. Cervical intraepithelial neoplasia grade III (CIN III) and invasive cervical carcinoma: the yawning gap revisited and the treatment of risk. Cytopathology 1999; 10:161-70.

15. Narducci F, Occelli B, Boman F, Vinatier D, Leroy JL. Positive margins after conization and risk of persistent lesion. Gynecologic Oncology 2000;76:311-4.

16. Mohamed-Noor K, Quinn MA, Tan J. Outcomes after cervical cold knife conization with complete and incomplete excision of abnormal epithelium: a review of 699 cases. Gynecologic Oncology 1997;67:34-8.

17. Jakus S, Edmonds P, Dunton C, King SA. Margin status and excision of cervical intraepithelial neoplasia: a review. Obstetrical and Gynecological Survey 2000;55:520-7.

18. Leguevaque P, Motton S, Decharme A, Soule-Tholy M, Escourrou G, Hoff J. Predictors of recurrence in high-grade cervical lesions and a plan of management. European Journal of Surgical Oncology 2010;36:1073-9.

19. Baloglu A, Uysal D, Bezircioglu I, Bicer M, Inci A. Residual and recurrent disease rates following LEEP treatment in high-grade cervical intraepithelial lesions. Archives of Gynecology and Obstetrics 2010;282:69-73.

20. Chen Y, Lu H, Wan X, Lv W, Xie X. Factors associated with positive margins in patients with cervical intraepithelial neoplasia grade 3 and postconization management. International Journal of Gynecology and Obstetrics 2009;107:107-10.

21. Chang D-Y, Cheng W-F, Torng P-L, Chen R-J, Huang S-C. Prediction of residual neoplasia based on histopathology and margin status of conization specimens. Gynecol Oncol. 1996;63:53-6.

22. Kliemann LM, Silva M, Reinheimer M, Rivoire WA, Capp E, Dos Reis R. Minimal cold knife conization height for high-grade cervical squamous intraepithelial lesion treatment. Eur J Obstet Gynecol Reprod Biol 2012; 165: 342-6.

23. Papoutsis D, Rodolakis A, Mesogitis S, Sotiropoulou M, Antsaklis A. Appropriate cone dimensions to achieve negative excision margins after large loop excision of transformation zone in the uterine cervix for cervical intraepithelial neoplasia. Gynecol Obstet Invest 2013; 75: 163-8.

24. Milinovic D, Kalafatic D, Babic D, Oreskovic LB, Grsic HL, Oreskovic S. Minimally invasive therapy ofcervical intraepithelial neoplasia for fertility preservation. Pathol Oncol Res 2009;15:521-5.

25. Baldauf JJ, Dreyfus M, Ritter J, Meyer P, Philippe E. Risk of cervical stenosis after large loop excision or laser conization. Obstet Gynecol 1996; 88: 933-8. [Crossref]

26. Girardi F, Heydarfadai M, Koroschetz F, Pickel $\mathrm{H}$, Winter R. Cold-knife conization versus loop excision: histopathologic and clinical results of a randomized trial. Gynecol Oncol 1994; 55: 36870. [Crossref]

27. Andia D, Mozo de Rosales F, Villasante A, Rivero B, Diez J, Perez C. Pregnancy outcome in patients treated with cervical conization for cervical intraepithelial neoplasia. Int J Gynaecol Obstet 2011; 112: 225-8. [Crossref] 


\title{
Резиме
}

\section{ФАКТОРИ ШТО ВЛИЈААТ ВРЗ СОСТОЈБАТА НА ЕКСЦИЗИОНИТЕ ХИРУРШКИ РАБОВИ КАЈ ПАЦИЕНТКИ КАЈ КОИ Е ИЗВЕДЕНА КОНИЗАЦИЈА СО КЛАСИЧНА ХИРУРШКА ТЕХНИКА - ИСКУСТВО ОД ЕДЕН ЦЕНТАР}

\author{
Игор Алулоски ${ }^{1}$, Миле Тантуровски $^{1}$, Гордана Петрушевска ${ }^{2}$, \\ Рубенс Јовановиќ ${ }^{2}$, Славица Костадинова-Куновска ${ }^{2}$ \\ ${ }^{1}$ Одделение за гинеколошка онкологија, Универзитетска клиника за гинекологија и акушерство, \\ Универзитет “Св. Кирил и Методиј““, Скопје, Република Македонија \\ ${ }^{2}$ Институт за Патологија, Медицински факултет, Универзитет “Св. Кирил и Методиј“, Скопје, \\ Република Македонија
}

Цел: Да се евалуираат факторите што влијаат врз состојбата на ексцизионите рабови на препаратот добиен кај пациентки со изведена оперативна хируршка техника - конизација на Универзитетската клиника за гинекологија и акушерство во Скопје, Македонија.

Материјал и методи: Направена е ретроспективна анализа на медицинските досиеја на сите пациентки кај кои е спроведена класична техника на конизација на нашата клиника во текот на 2015 год. Направивме компарација меѓу состојбата на ексцизионите рабови на конизатот со добиените хистопатолошки дијагнози (LSIL, HSIL или микроинвазивен/инвазивен карцином), менопаузалниот статус на пациентките, бројот на бремености, искуството на хирургот, времетраењето на операцијата и длабочината на конусот. Добиените податоци беа анализирани со $\chi 2$-тест, Фишеров егзактен тест и Стутентов т-тест, како и спроведување на униваријантна и мултиваријантна регресивна анализа.

Резултати: Вкупно беа анализирани 246 медицински досиеја. Од тоа, кај 29 (11,79\%) пациентки утврдена е LSIL промена, кај 194 (78,86\%) утврдена е HSIL и кај 23 (9,34\%) од пациентките утврден е микроинвазивен/инвазивен карцином. Ексцизионите хируршки рабови на конизатот беа позитивни кај $78(31,7 \%)$ од пациентките. Просечната старост на пациентките изнесува 41,13, а 35 (14,23\%) од пациентките се во менопауза. Мултиваријантната логистичка регресивна анализа ги идентификуваше: предоперативниот хистолошки наод на микроинвазивен карцином на грлото на матката добиен со биопсија, постоперативен хистолошка наод на HSIL или понапредната дијагноза на препаратот добиен со конизација и помалата длабочина на конизатот, како независни предиктори за инволвирање (позитивни) ексцизиони хируршки рабови на конизатот, добиен кај пациентки кај кои е спроведена класична техника на конизација со скалпел.

Заклучок: Во оваа студија не е утврдена поврзаност меѓу карактеристиките на пациентките и искуството на хирургот со инволвираноста на есцизионите хируршки рабови на конизатот. Најважни предиктори за позитивни рабови на препаратот (конизатот) претставува тежината на лезијата на грлото на матката, потврдена преку хиспатолошкиот наод и длабочината на конизатот.

Клучни зборови: конизација, резидуална болест, хируршки маргини 